\title{
THE INFLUENCE OF SPIRITUAL LEADERSHIP ON SPIRITUAL AND MATERIAL MOTIVATION AND ITS IMPACT ON SERVICE QUALITY: CASE OF GRAND PERMATA HATI HOTEL BANDA ACEH
}

\author{
*Ichsan Akmal Mazas, Sofyan, M. Shabri \\ Management Department, Universitas Syiah Kuala, Indonesia \\ http://doi.org/10.35409/IJBMER.2021.3274
}

\begin{abstract}
The purpose of this research was to examine the effect of spiritual leadership on spiritual motivation and material motivation and its impact on the quality of service. The population was all the consumers at the Grand Permata Hati Hotel Banda Aceh at the end of 2018. The sample taken was 150 respondents. The data analysis tool used in this research is a verification test using structural equation modeling (SEM), operated by the AMOS software. The result concluded that Spiritual leadership positively affected the spiritual motivation of employee at the Grand Permata Hati Hotel, Banda Aceh City; Spiritual leadership positively affected the material motivation of employee at the Grand Permata Hati Hotel, Banda Aceh City; Spiritual leadership positively affected service quality of employee at the Grand Permata Hati Hotel, Banda Aceh City; Spiritual motivation positively affected service quality of employee at the Grand Permata Hati Hotel, Banda Aceh City; Material motivation positively affected service quality of employee at the Grand Permata Hati Hotel, Banda Aceh City; Spiritual leadership positively affected service quality through the spiritual motivation of employees at the Grand Permata Hati Hotel, Banda Aceh City, and; Spiritual leadership positively affected service quality through the material motivation of employee at the Grand Permata Hati Hotel, Banda Aceh City. The novelty of the research lies in the use of previous theories of causality which are combined to build the current research model, namely the model needed to improve service quality from the perspective of spiritual leadership, spiritual motivation, and material motivation. For further researches, it is suggested not to focus on one hotel, but several Islamic hotels as objects of comparative research. It is also advisable to examine Islamic hotels and non-Islamic hotels to provide comparisons of various aspects.
\end{abstract}

Keyword: Spiritual Leadership, Spiritual Motivation, Material Motivation, and Quality of Service.

\section{INTRODUCTION}

The development of the service industry has penetrated various fields, such as the hotel industry, education, and medical services. The service industry required human resources with high qualifications to satisfy customers becomes a mandatory requirement in this industry. A good work culture system and high work motivation could bring the organization to achieve the fulfillment of individual needs. Human resources in a company must priority to improve 


\section{International Journal of Business Management and Economic Review}

Vol. 4, No. 03; 2021

ISSN: 2581-4664

performance, develop a culture of the organization that supports innovation and flexibility (Zainal, Hadad, \& Ramly, 2019). A good organizational culture must be able to improve performance, individual or organization.

The development of the tourism industry in Indonesia is increasing every year. This is evident with increasing the tourist, national and international tourist. Every tourist who comes to each area needs accommodation to stay in or commonly called Hotel.

Hotel is the industry of service which is quite complicated to manage, provided every facility that can be used by the guest for 24 Hours. Therefore, the Hotel business can also support the activities of the businessman who are on a business trip or when they travel to visit tourist areas and need a place to stay, eat and drink as well as entertainment. For example, one of the business in the hospitality industry is the Grand PermataHati Hotel which is located in Banda Aceh city, Indonesia, (in this study it is referred to as the Grand PermataHati Hotel Banda Aceh) which is the only hotel in Aceh Province that has received an official certificate as a Sharia hotel by the National Sharia Council - the Indonesian Ulama Council.

Therefore, the intense competition in the hospitality business has spurred every hotel management to always try to find solutions so that the business continues to grow. For that, every hotel business is required to carry out several management improvement programs, cost savings without reducing service to customers in order to have competitiveness for competence. Service quality in this case is closely related to productivity which has a reference to organizational performance. So to ensure the survival of the organization, various techniques for increasing productivity must be developed. The hospitality industry is expected to have a quality of human resources because hotels are engaged in services that prioritize service quality. Almost all hotels have almost the same facilities, the difference is the culture and quality of service that each hotel has. To be able to win the hotel competition, it is very necessary to do continuous innovation in order to meet the ever-changing wants and needs of customers.

The success of a company is also influenced by employee performance (Job Performance) or the work achieved by an employee in performing tasks following the responsibilities assigned to him. Employees are an important resource for the company because they have the talent, energy, and creativity that the organization needs to achieve its goals. Factors that affect performance are ability and motivation factors. Organizational culture serves to form rules or guidelines in thinking or acting in achieving the goals set. This means that an organizational culture that grows and is well maintained will be able to spur the organization towards better development. In addition, the main stress in the change and development of organizational culture is trying to change the values, attitudes, and behavior of the members of the organization as a whole. In fulfilling the expectation of good service quality, the company must have several factors that will be implemented and implemented in a system, one of which is the motivation of employees to work better and better supported by spiritual leadership. The ability of a leader in running the wheels of the company plays an important role. However, in this case, the problem can be seen in the object under study, namely the lack of employee motivation, resulting in ups and downs of morale which in the end also has an impact on the quality of service provided to guests staying at the Grand PermataHati Hotel, Banda Aceh.

Motivation factors for employees at work can come from spiritual motivation or material motivation. Most employees work in hotels only based on the salary/wages given, not because of work motivation as worship. So, if work is only based on material, then this can be seen from the 


\section{International Journal of Business Management and Economic Review}

Vol. 4, No. 03; 2021

ISSN: 2581-4664

insincerity of employees in providing services or careless origin. However, if work is based on spiritual motivation, that is, work is a form of worship, then sincerity and sincerity will have an impact on the quality of service provided. This of course must be driven by strong leadership and spiritual root.

Big change full of turmoil and challenges requires the ability to make strategies in accordance with the demands of these changes, ranging from social, economic, cultural, to technological changes. The quality of leadership in the company is influenced by at least three things, namely the maturity of the leader himself, a strong understanding from a leader of the company's business and its processes, and the very high awareness and willingness of company stakeholders to create a positive performance. The goal of spiritual leadership is to touch the basic need of leaders and followers for spiritual survival through calling and membership. So that it can create a vision and value congruence for all individuals, empowering teams, and at the organizational level, which in turn leads to higher levels of organizational commitment and productivity.

\section{LITERATURE REVIEW}

\section{Quality of Service}

(Kotler \& Keller, 2018) stated that service is any action or action that a party can offer to another party that is intangible and does not result in ownership of something.According to (Zeithaml, Bitner, \& Gremler, 2018), services are "economic activities with output other than products in a physical sense, consumed and produced at the same time, providing added value and in principle being intangible for the first buyer". Furthermore, (Wirtz, Chew, \& Lovelock, 2012) argued that service is a system consisting of 2 (two) components, namely (1) service operations, where input is processed and service product elements are created and (2) service delivery in which elements of the service product are assembled, finalized and delivered to service users, part of the system is visible or known to the service user (front office/frontstage) and others are not the service user is visible or completely unknown (back office/backstage).

In providing services, service providers must understand the wants/needs of service users for the services provided, these needs consist of practical needs which include perceived value in tangible forms (tangibles) such as instruments, tools and tangible facilities. and seen and emotional needs (emotional needs) include the value of a physiological sense that is met from the attitudes, actions and behavior of service providers (Rahmayanty, 2013).

Based on the level of interaction between service providers and users, these services can be grouped into high-contact services and low-contact services. As for the high-contact services group in receiving services, service users must position themselves to be part of the system being implemented such as universities, banks, doctors, consultants, while for the low-contact services group, service users do not have to position themselves as part of the system run such as telecommunication services, postal services, workshops.

Based on the understanding raised by the experts above, it can be concluded that service is basically an activity that has several intangible elements that can be provided by service providers to service users and can provide various benefits for the parties. Associated with the need for these services.

The level of service user satisfaction depends on the quality of service that the service user expects from the service provider, the closer the quality of the service provided to the 


\section{International Journal of Business Management and Economic Review}

Vol. 4, No. 03; 2021

ISSN: 2581-4664

expected service quality, the smaller the level of difference in service user disappointment, for the services they receive, both in the form of goods and services.

(Kotler \& Keller, 2005) stated, "quality is a dynamic condition that relates well to products, services, people, processes and the environment that meet or exceed expectations". Furthermore, (Lewis \& Booms, 1983) defined "service quality is as a measure of how well the level of service provided by service providers is able and in accordance with the expectations of service users. Thus the quality of service can be realized through fulfilling the needs and desires of service users and the accuracy of its delivery to match the expectations of service users.

Quality, as defined for higher education, has been identified by (Harvey \& Knight, 1996), they suggested that quality reflects outstanding, consistency, fitness for purpose, value for money, and is transformative. (Kotler \& Keller, 2018) stated that "service quality must start from the needs of service users and end with service user satisfaction and a positive perception of the quality of services provided by service providers". Likewise, according to (Kotler \& Keller, 2005) which stated "service quality must start from the needs of service users and end with the perceptions of service users, so that good quality is not based on the wishes and perceptions of service providers but based on the desires and perceptions of service users who use these services".

Quality has a close relationship with service user satisfaction, quality provides an impetus for service users to forge strong long-term ties with the company. This emotional bonding will enable service providers to understand the expectations and specific needs of service users in order to increase service user satisfaction which contributes to the creation of switching barriers, switching costs and loyalty of service users.

If the expectations of a service user for a product are achieved then for further product development it will be easier to maintain and get loyal consumers of a product/service. Thus service quality is an overall concept, from service aspects, how its characteristics and consistency are felt by service users or service users. The suitability between what is felt and what is expected from all aspects of the service is said to be satisfaction, the higher the match between what is felt and what is expected, the higher the value of user satisfaction. Thus, whether the quality of the service is good or not depends on the ability of service providers to consistently meet service user expectations.

\section{Work Motivation}

Motivation according to (Herzberg, Mausner, \& Snyderman, 2011) is the power in a person to provide power and strength to do something. In other words, motivation can be defined as the process of giving encouragement to employees to do something without feeling forced.

Motivation according to (Nawaz, 2011) is a change in energy in a person characterized by the emergence of feelings and is preceded by a response to a goal. Research conducted by (Listianto, 2006) stated that work motivation has a positive and significant effect on employee performance. From previous research, the relationship between motivation and performance is directly proportional. This means that the higher the employee's motivation to work, the higher the resulting performance.

In terms of improving better performance, one way is to motivate employees so that they can improve their performance better. In this case, the meaning of motivation is defined as the willingness to put out a high level of effort towards organizational goals, in order to meet 


\section{International Journal of Business Management and Economic Review}

Vol. 4, No. 03; 2021

ISSN: 2581-4664

some individual needs. With high motivation and self-confidence, employees will always try to give their best for the work for which they are responsible. An attitude of mutual respect, mutual need, mutual understanding and respect for each other's rights and obligations will be formed (Mahdani, Hafasnuddin, \& Adam, 2017).

\section{Spiritual Motivation}

Spiritual motivation is the power in a person to do something based on spiritual beliefs and spiritual needs. Spiritual needs are natural needs whose fulfillment depends on human perfection and individual maturity (Ancok, 2012).Motivation is a psychological process that enhances and directs behavior to achieve goals. Humans need a three-dimensional portfolio goal to measure themselves in three layers, namely: material, intellectual, and spiritual. Spirituality can be described as a praxis of freedom, a way of living by concentrating on the process of discovering who we are and how we want to act. (Agustian, 2016) emphasizes that one of the motivations that drives someone to do activities is spiritual motivation. Spiritual motivation involves a person's awareness that he has a relationship with God the Creator himself and the universe. The spiritual element in humans makes us ask why we do something and makes us look for fundamentally better ways to do it (Zohar, 2005).

The spiritual motivation variable is manifested by the intensity of remembering Allah (dzikir), the impulse of one's need, the degree of confidence in praying, and the seriousness of the effort to imitate the beautiful nature of Allah. Attitude variables in organizational culture are manifested by the degree of communication, fairness, relationships, trust, truth, power, flexibility, and empowerment.Maslow divides two classifications of motivation: primary motivation and spiritual motivation. Spiritual needs are natural needs whose fulfillment depends on human perfection and individual maturity (Ancok, 2012). It seems that there is a big contribution to the spiritual importance of a person who affects a person's psychology at work, which will significantly affect their performance (Latham, 2011).

\section{Material Motivation}

Material motivation or material incentives is material motivation as a reward for performance such as overtime pay, bonuses, and so on. According to (Robins \& Coulter, 2012), the reward in question is something that employees receive as a contribution for the services they provide to the company. Work motivation based on materials can be in the form of cash in kind, directly or indirectly.

\section{Spiritual Leadership}

According to (Siagian, 2014) leadership is a person's ability to influence others, in this case his subordinates, in such a way that the other person is willing to do the will of the leader even though personally it may not be liked. Then according to (Hasibuan, 2014), a leader is someone with the authority of his leadership to direct his subordinates to do some of their work in achieving goals. So that leadership is someone who has the nature of being able to use his authority to be able to direct his subordinates to do some of his work in achieving organizational goals. Leadership is basically about creating ways for people to contribute to making something extraordinary happen. So that the conclusion is that leadership is one of the organizational 


\section{International Journal of Business Management and Economic Review}

Vol. 4, No. 03; 2021

ISSN: 2581-4664

functions that allows a person to be able to influence others to be able to do a job in order to achieve an organizational goal.

The role of a very large leader affects employees, as stated in Nowack's research that bad leadership practices cause employees to leave the organization. Meanwhile, according to (Siagian, 2014), leaders in an organization have the following roles (1) Interpersonal roles, that interpersonal roles manifest themselves in three forms, namely as a symbol of the existence of the organization (played in various activities that are legal and ceremonial), (2) Role which is informational, this role takes three forms, namely First, the role of monitoring the flow of information. Second, the role as divider or disseminator of information; Third, the role as spokesperson for the organization (3) The role of decision-making, this role takes four forms, namely First, as an entrepreneur; Second, as a silencer; Third, as the divider of funds and resources; The fourth is acting as a negotiator for the organization.

\section{Research Hypothesis}

Based on the literature and issues above, the authors build the hypothesis in this research, are:

H1 : Spiritual leadershippositively affected spiritual motivation of employee at the Grand PermataHati Hotel Banda Aceh

$\mathrm{H} 2$ : Spiritual leadership positively affectedmaterial motivation of employee at the GrandPermataHati Hotel Banda Aceh

H3 : Spiritual leadership positively affected service quality of employee at the GrandPermataHati Hotel Banda Aceh

H4 : Spiritual motivation positively affectedservice quality of employeeat the Grand PermataHati Hotel Banda Aceh

H5 : Material motivation positively affected service quality of employeeat the Grand PermataHati Hotel Banda Aceh

H6 : Spiritual leadership positively affected service quality through the spiritual motivation of employees at the Grand PermataHati Hotel Banda Aceh

H7 : Spiritual leadership positively affected service quality through material motivation of employee at the GrandPermataHati Hotel Banda Aceh

\section{RESEARCH METHOD}

\section{Location and Variable}

This research was conducted at the Grand PermataHatiHotel,located in Banda Aceh city, Indonesia. The variables of research are spiritual leadership, spiritual motivation, material motivation, and service quality.

\section{Population and Sample}

The population in this study was all consumers who have stayed at the Grand PermataHati Hotel, where until the end of November 2018 the authors took 150 respondents as a sample.

\section{Data Analysis Tool}




\section{International Journal of Business Management and Economic Review}

Vol. 4, No. 03; 2021

ISSN: 2581-4664

Data analysis and research interpretation are intended to answer research questions in order to reveal certain social phenomena. Data analysis is the process of simplifying data into a form that is easier to read and implement. The method chosen to analyze the data must be in accordance with the research pattern and the variables to be studied. In this study, to analyze the data used The Structural Equation Modeling (SEM) from the statistical software of AMOS in modeling and hypothesis analysis. The SEM equation model is a set of statistical techniques that allow testing a series of relatively "complex" relationships simultaneously (Ferdinand, 2014).

\section{RESULT}

Spiritual leadership in affecting spiritual motivation of employee at Grand PermataHati Hotel Banda Aceh

Testing the influence of spiritual leadership on spiritual motivation resulted a CR value of 4.298 and a p-value of 0.000 . These two values obtained meet the requirements for $\mathrm{H} 1$ acceptance, which are the CR value $>1.97$ and the $\mathrm{p}$-value $<0.05$.

Spiritual leadership in affectingmaterial motivation of employeeof Grand PermataHati Hotel Banda Aceh

Testing the effect of spiritual leadership on employee material motivation resulted a CR value of 6.432 and a p-value of 0.000 . These two values obtained meet the requirements for $\mathrm{H} 2$ acceptance, which are the CR value $>1.97$ and the $\mathrm{p}$-value $<0.05$.

Spiritual leadership in affecting quality of service of employees of Hotel Grand PermataHati Banda Aceh

Testing the influence of spiritual leadership on spiritual motivation resulted a CR value of 7.857 and a p-value of 0.000 . These two values obtained meet the requirements for acceptance of $\mathrm{H} 3$, which are the $\mathrm{CR}$ value $>1.97$ and the $\mathrm{p}$-value $<0.05$.

Spiritual leadership in affecting quality of service of employee of Hotel Grand PermataHati Banda Aceh

Testing the influence of spiritual leadership on spiritual motivation resulted a CR value of 7.857 and a p-value of 0.000 . These two values obtained meet the requirements for acceptance of $\mathrm{H} 3$, which are the CR value $>1.97$ and the $\mathrm{p}$-value $<0.05$.

Spiritual motivation in affecting quality of service of employee of Hotel Grand PermataHati Banda Aceh

Testing the effect of employee spiritual motivation on the Grand PermataHati Hotel Banda Aceh resulted a CR value of 6.713 and a p-value of 0.000 . These two values obtained meet the requirements for acceptance of $\mathrm{H} 4$, which are the CR value $>1.97$ and the pvalue $<0.05$.

Material motivation in affecting quality of service of employee of Hotel Grand Permata Hati Banda Aceh

The estimation parameter for testing the effect of material motivation on the service quality of the employees of the Grand PermataHati Banda Aceh hotel resulted a CR value of 3.920 and a p-value of 0.000 . The two values obtained meet the requirements for acceptance of H5, which are the CR value $>1.97$ and the $p$-value $<0.05$. Thus it can be concluded that material motivation will affect the quality of service at the Grand PermataHati Banda Aceh Hotel. 


\section{International Journal of Business Management and Economic Review}

Vol. 4, No. 03; 2021

ISSN: 2581-4664

Spiritual leadership in affecting spiritual motivation through quality of service of employee of Hotel Grand Permata Hati Banda Aceh

Based on the results of the estimation, the estimated value for testing the effect of spiritual leadership on service quality through spiritual motivation has a direct value of 0.268 , while the indirect effect is 0.472 and the total effect is 0.126 . This indicates that the indirect influence of spiritual leadership on the quality of service through spiritual motivation is smaller than the direct effect. The results of this study are consistent with research conducted by (Tobroni, 2005) that the understanding of spirituality in work. Spirituality is the essence of the relationship between the individual spirit and soul which is holy, the source of truth, or God that humans believe in and how to apply it to all people. Leadership has developed at this time in fixing the leadership crisis due to the decline in human values as a result of the ethical malaise and ethical crisis.

\section{Spiritual leadership in affecting material motivation through quality of service of employee} of Hotel Grand Permata Hati Banda Aceh

Based on the results of the estimated value for testing the effect of spiritual leadership on material motivation through service quality, the direct value is 0.243 , while the indirect effect is 0.019 and the total effect is 0.262 . This indicates that the indirect influence of spiritual leadership on material motivation through service quality is greater than the direct effect.

\section{CONCLUSION}

The result concludes that Spiritual leadership positively affected spiritual motivation of employee at the Grand PermataHati Hotel Banda Aceh; Spiritual leadership positively affected material motivation of employee at the Grand PermataHati Hotel Banda Aceh; Spiritual leadership positively affectedservice quality of employee at the Grand PermataHati Hotel Banda; Spiritual motivation positively affectedservice quality of employeeat the Grand PermataHati Hotel Banda Aceh; Material motivation positively affected service quality of employeeat the Grand PermataHati Hotel Banda Aceh; Spiritual leadership positively affectedservice quality through the spiritual motivation of employees at the Grand PermataHati Hotel Banda Aceh, and; Spiritual leadership positively affectedservice quality through material motivation of employee at the Grand PermataHati Hotel Banda Aceh.The novelty of research lies in the use of previous theories of causality which are combined to build the current research model, namely the model needed to improve service quality from the perspective of spiritual leadership, spiritual motivation and material motivation.

This contributes to academic as a theory development. For further researches, it is suggested not to focus on one hotel, but several Islamic hotels as objects of comparative research. It is also advisable to examine Islamic hotels and non-Islamic hotels to provide comparisons of various aspects. Also, some recommendations for practitioners in Grand PermataHati Hotel can be provided. To improve the quality of service, spiritual leadership must be enhanced by increasing true honesty at work, so that it becomes a good foundation for work.Besides, what needs to be instilled in employees is the principle of work asa part of worship, so their spiritual motivation can increase. For material motivation, the provision of adequate wages is the important thing to be considered so that employees have their daily needs met. 
Vol. 4, No. 03; 2021

ISSN: 2581-4664

\section{REFERENCES}

Agustian, R. (2016). Gaya Kepemimpinan Kepala Sekolah Dalam Meningkatkan Motivasi Kerja Guru. MAPEN: Jurnal Manajer Pendidikan, 10(1), 88-95.

Ancok, D. (2012). Psikologi Kepemimpinan \& Inovasi. Jakarta: Erlangga.

Ferdinand, A. (2014). Structural Equation Modeling dalam Penelitian Manajemen (5th ed.). Semarang: Badan Penerbit Universitas Diponegoro.

Harvey, L., \& Knight, P. T. (1996). Transforming Higher Education. Oxfordshire United Kingdom: Taylor and Francis.

Hasibuan. (2014). Manajemen Sumber Daya Manusia. In Manajemen Sumber Daya Manusia (Revisi). Jakarta: Bumi Aksara.

Herzberg, F., Mausner, B., \& Snyderman, B. B. (2011). The Motivation to Work. New Jersey: Transaction Publishers.

Kotler, P., \& Keller, K. L. (2005). Marketing Management. New Jersey: Pearson Prentice Hall.

Kotler, P., \& Keller, K. L. (2018). Marketing Management, Global Edition (15th editi). Harlow, United Kingdom: Pearson.

Latham, G. P. (2011). Work Motivation: History, Theory, Research, and Practice. New York: SAGE Publications.

Lewis, C., \& Booms, B. (1983). The Marketing Aspects of Service Quality. Emerging Perspectives in Service Marketin, 65(4), 99-107.

Listianto, T. (2006). Pengaruh Motivasi. Kepuasan Dan Disiplin Kerja Terhadap Kinerja Karyawan (Studi Kasus Di Lingkungan Pegawai Kantor PDAM Kota Surakarta). Universitas Muhammadiyah Surakarta.

Mahdani, F., Hafasnuddin, \& Adam, M. (2017). Pengaruh Motivasi, Kecerdasan Emosional Dan Keadilan Organisasi Terhadap Kepuasan Kerja Serta Implikasinya Pada Kinerja Karyawan ( Studi Pada Kanwil Pt . Bank Rakyat Indonesia (Persero) Tbk. Banda Aceh. Jurnal Magister Manajemen, 1(1), 1-15.

Nawaz, A. S. M. S. (2011). Employee motivation: A study on some selected McDonalds in the UK. African Journal of Business Management, 5(14), 5541-5550.

Rahmayanty, N. (2013). Manajemen Pelayanan Prima; Mencegah Pembelotan dan Membangun Customer Loyality. Yogyakarta: Graha Ilmu.

Robins, S. P., \& Coulter, M. (2012). Management (11th Ed). In Prentice Hall. https://doi.org/10.1002/1521-3773(20010316)40:6<9823::AID-ANIE9823>3.3.CO;2-C

Siagian, S. P. (2014). Manajemen Sumber Daya Manusia. Jakarta: Bumi Aksara.

Wirtz, J., Chew, P. Y., \& Lovelock, C. (2012). Essentials of Services Marketing (2nd ed.). London: Pearson Education.

Zainal, V. R., Hadad, M. D., \& Ramly, M. (2019). Kepemimpinan dan Perilaku Organisasi (4 Ed). Depok: Raja Grafindo Persada.

Zeithaml, V., Bitner, M. J., \& Gremler, D. (2018). Services Marketing: Integrating Customer Focus Across the Firm (7th ed.). New York: McGraw-Hill.

Zohar, D. (2005). Spiritually intelligent leadership. Leader to Leader, 38, 45-51. https://doi.org/https://doi.org/10.1002/lt1.153 